\title{
Primary bladder amyloidosis mimicking bladder cancer complicated by bladder rupture: A case report
}

\author{
Rayan Sibira ${ }^{1}$, Ahmed Albakr ${ }^{1}$, Nagy Younes ${ }^{1}$, issam AL-Bozom ${ }^{1}$, and Khalid Alrumaihi ${ }^{1}$ \\ ${ }^{1}$ Hamad Medical Corporation
}

August 5, 2021

\begin{abstract}
Primary bladder amyloidosis is a rare pathological finding. The clinical importance of this finding is that it may clinically mimic bladder cancer. The only accurate diagnostic method available till now is the histopathologic examination of tissue samples usually obtained through transurethral resection.
\end{abstract}

\section{Hosted file}

Bladder amyloidosis.pdf available at https://authorea.com/users/429289/articles/533009primary-bladder-amyloidosis-mimicking-bladder-cancer-complicated-by-bladder-rupture-acase-report 